\title{
WIZERUNEK CHINEK W WYBRANEJ POLSKIEJ PRASIE MIĘDZYWOJENNEJ W LATACH 30. XX W.
}

Historia zainteresowania polskiej prasy Chinami sięga 1889 r., kiedy to na łamach „Prawdy” ukazywały się informacje na temat powstania bokserów ${ }^{1}$. Państwo to fascynowało obywateli II Rzeczypospolitej przede wszystkim swoją bogatą i z europejskiego punktu widzenia egzotyczną kulturą. Może o tym świadczyć fakt, że na łamach polskiej prasy w odniesieniu do Chin stosowano poetyckie nazwy, jak: Państwo Środka ${ }^{2}$, Państwo Smoka ${ }^{3}$, Państwo Niebieskiego Smoka ${ }^{4}$, Państwo Złotego Smoka ${ }^{5}$, Państwo Niebieskie ${ }^{6}$, Niebieskie Państwo ${ }^{7}$, Podniebne Państwo ${ }^{8}$ oraz Państwo Niebieskiego Środka ${ }^{9}$, a ich mieszkańców nazywano Synami Nieba ${ }^{10}$ albo Dziećmi Smoka ${ }^{11}$.

Nie tylko dziedzictwo cywilizacyjne Chin, lecz także istnienie polskiej diaspory w Szanghaju i Harbinie, która utrzymywała prężne kontakty z rodakami w ojczyźnie, wpływało na wzrost zainteresowania tym państwem. Ponadto na łamach polskiej prasy czytelnicy mogli uważnie śledzić rozwój wieloletniego konfliktu

ORCID: 0000-0002-1011-906X, DOI: 10.4467/23538724GS.21.006.14838

1 J. Bachórz, „Prawda” Aleksandra Świętochowskiego o chińskim Powstaniu Bokserón [w:] Chiny w oczach Polakón, red. J. Włodarski, K. Zeidler, M. Burdelski, Gdańsk 2010, s. 349-351.

2 G., Skraydlaci Fabrykanci Jedwabiu, „As”, nr 22, 30.05.1937, s. 16-17; B. Bourke, Radości i smutki drieci smoka, „Na Szerokim Świecie”, nr 12, 21.03.1937, s. 12; R. Fengler, „Nowe życie” Mussoliniego Chin, „Tęcza”, styczeń 1937, nr 1, s. 40.

3 R. Fengler, „Nowe ṡycie”..., s. 38; A.M., Wieczór w Pekinie, „Na Szerokim Świecie”, nr 33, 15.08.1937, s. 4; Dr. K. Zieliński, Mała podróż musyczna naokoło śniata, „Tęcza”, grudzień 1937, nr 12 , s. 57.

4 M. Turski, Chinski teatr cieni, „As”, nr 30, 25.07.1937, s. 15.

5 T. Piszkowski, Ameryka i Japonja na Pacyfiku, ,Wschód”, sierpień-wrzesień 1932, nr 7-8, s. 32,33 .

6 Ibidem; Dr. St. Bernatt, Sztuka chińska, „Tęcza”, kwiecień 1934, nr 4, s. 48; B. Prus, Z roc₹ników chinskich, „Tęcza”, luty 1935, nr 2, s. 12-14; W. Somerset Maugham, Fanningowie, tłum. I. Dobrzycka, „Tęcza”, maj 1935, nr 5, s. 45-48.

7 Romans cesarza Pu-Yi - tajemnice dworu mandìurskiego, „Na Szerokim Świecie”, nr 29, 18.07. 1937, s. 7.

8 U. Piechocka, List ₹. S zanghaju, „Tęcza”, czerwiec 1938, nr 6, s. 74.

9 J. Mąkolska, Do Chin, „Bluszcz”, 6.04.1935, nr 14, s. 419.

10 B. Bourke, $W$ Chacie Syna Nieba, „Na Szerokim Świecie”, nr 16, 18.04.1937, s. 6.

11 B. Bourke, Radości i smutki dzieci smoka, „Na Szerokim Świecie”, nr 12, 21.03.1937, s. 13. 
chińsko-japońskiego - jego pierwszym etapem był incydent mukdeński, kiedy to 18 września 1931 r. armia kwantuńska zaatakowała, a następnie zajęła Mandżurię.

W polskiej prasie starano się przybliżyć czytelnikom mieszkańców Państwa Środka. Wiele miejsca poświęcano przede wszystkim Chinkom. Publikacje na ten temat pojawiały się zazwyczaj na łamach czasopism masowych, takich jak sensacyjny „As”12 i podróżniczo-geograficzne „Na Szerokim Świecie”, a także ukazujący się we Lwowie krajoznawcze „Z Bliska i z Daleka” oraz czasopisma kobiece „Bluszcz” i „Ziemianka Polska”. Sporadycznie informacje na ten temat pojawiły się również w specjalistycznych czasopismach: orientalistycznym i prometejskim „Wschodzie”, poświęconym kulturze „Teatrze” i „Życiu Sztuki”, skierowanym do wojskowych „Żołnierzu Polskim” oraz religijno-społecznym: „Przeglądzie Katolickim” i „Tęczy”.

Autorzy artykułów o Chinach wiele miejsca poświęcali opisom kobiet, zarówno ich wyglądowi zewnętrznemu, jak i duchowości. Czytelnicy „Asa” mogli dowiedzieć się, że kobieta Wschodu była piękna, uwielbiana, ale także „tonąca w morzu przesądów”", a w „Bluszczu” pisano, że są one: tajemnicze, mało znane i dopiero kilku lat temu wyrwały się z półniewoli ${ }^{14}$. Mieszkanki Państwa Środka miał charakteryzować odmienny od europejskiego urok. Korespondent „Na Szerokim Świecie” tak komplementował wdzięk swojej znajomej: „Te ciemne, czarne, wielkie błyszczacce wprost niesamowicie, skośne oczy mej sąsiadki posiadały w sobie coś, może tajemniczego, co przeszywało dreszczem, może się w nich czaiła dusza wschodu ${ }^{15}$. Mieszanina mistycyzmu, okrucieństwa i dobroci”16. Natomiast, w noweli opublikowanej w „Asie” główną bohaterkę opisywano tymi słowami: „Chinka! Kobieta wschodu. Inna dusza, inna wiara, inne wnętrze. Inna skóra i postać, i oczy, i słowa. Niezbadana, kusząca, brzydka i cudowna. Męcząca. Upajająca jak haszysz, jak opium, jak kokaina... Chinka!"17.

Ponadto, jak wskazywali dziennikarze, chińskie damy były wyjątkowo wytworne, a ich atutem stały się najpiękniejsze na świecie dłonie. Sekret ich urody tkwił w tym, że nie wykonywały nimi zbędnych ani gwałtownych ruchów, a także potrafiły o nie odpowiednio zadbać ${ }^{18}$. Warto podkreślić, że uwaga ta odnosiła się jedynie do zamożnych mieszkanek Państwa Środka. Urodę Chinek wspominano także przy okazji reklamy pudru o nazwie „Pani Czang”19. Według dziennikarzy „Asa” i „Na Szerokim Świecie" symbolem chińskiej urody była aktorka filmowa i teatralna, a także modelka - May Wong ${ }^{20}$. Współpracownik „Bluszczu” z kolei wskazywał szang-

12 Czasopismo wydawane przez koncern Ilustrowany Kurier Codzienny.

3 Japonka u siebie, „As”, nr 28, 8.09.1935, s. 28.

14 Amicus, Japonki, „Bluszcz”, nr 5, 30.01.1932, s. 9.

15 Zapis od małej litery w oryginale tu i w kolejnym cytacie.

16 A.M., W herbacianym domku, „Na Szerokim Świecie”, nr 34, 22.08.1937, s. 12.

17 A. Teodorowicz, Hansu - nowela, „As”, nr 35, 28.08.1938, s. 23-25.

18 Carmen, „Badźmy mtodzi i piekeni”! - Recepta chińskiej lady, „As”, nr 4, 24.03.1935, s. 29.

19 Reklama pudru: „Pani Czang”, „Na Szerokim Świecie”, nr 34, 22.08.1937, s. 12.

20 A.M., W herbacianym domku..., s. 12.; Anna May Wong pozuje..., „As”, nr 5, 2.02.1936, s. 27. Warto dodać, że wspomniana artystka jako pierwsza Amerykanka chińskiego pochodzenia 
hajską śpiewaczkę operową Wu-Su-Hung ${ }^{21}$. Dodawał przy tym, że Chinki chodziły drepczącym krokiem ${ }^{22}$. Natomiast dendrolożkę Fu Liang Chang opisywał tymi słowami: „wyróżniała się ciemną cerą, czarnymi oczami oraz dyskretnym wschodnim charakterem twarzy" ${ }^{\prime 2}$.

Negatywnie o urodzie Chinek wypowiadał się jedynie korespondent Edward Kuryło na łamach „Teatru”. Według niego kobiety nakładające na swoją twarz biel i róż wyglądały jak „okropne maszkary” ${ }^{24}$. Zdaniem innego korespondenta, współpracującego z czasopismem „Na Szerokim Świecie”, również Chinki miały wiele zastrzeżeń do zachodniego kanonu urody i wręcz odczuwały wstręt do Europejczyków. Dlatego, jak twierdził na podstawie własnych obserwacji, małżeństwa Chinek z Europejczykami należały do rzadkości ${ }^{25}$.

Niewiele miejsca w polskiej prasie omawianego okresu poświęcono cechom charakteru Chinek, a jeśli to czyniono, ukazywano je w negatywnym świetle. Według Emila Theobalda, piszącego dla „Naokoło Świata”, rodowita Chinka miała być uczciwa, ale zarazem głupia i nieobyta. Ponadto zazwyczaj nie żywiła cieplejszych uczuć do męża, lecz traktowała go przedmiotowo. Często bowiem wraz z innymi żonami tworzyła wspólny front, aby wymusić na małżonku zakup bogatych strojów i klejnotów ${ }^{26}$. Przekonania te wskazuja, że dziennikarze piszący dla popularnej prasy postrzegali zazwyczaj Daleki Wschód przez pryzmat arystokracji, aktorek i aktorów.

W podobny, negatywny sposób ukazano kobietę w chińskiej legendzie Źródło bogón, opublikowanej na łamach „Naokoło Świata” w 1937 r. Opowiada ona historię pary staruszków: drwala Czen-Men i jego marudnej żony Li-Wu, którzy pewnego razu napili się wody z cudownego źródełka. Wkrótce po tym zdarzeniu Czen-Men na powrót stał się młodzieńcem, a jego żona, która z powodu chciwości wypiła zbyt dużo wody - niemowlęciem. Drwal więc wychował swoją żonę jak córkę, dzięki czemu Li-Wu stała się spokojna, mądrą i pilną kobietą. Opowieść ta według autora wyjaśniała, dlaczego Chińczycy oddają na wychowanie swoje córki rodzinie jej przyszłego męża ${ }^{27}$. Publikacja tej legendy może wskazywać, jak redaktorzy wyobrażali sobie ideał chińskiej żony i jak objaśniali niezrozumiałe z europejskiego punktu widzenia tradycje. Prawda jest, że małżeństwa w Chinach były aranżowane nawet

zdobyła międzynarodową sławę, a także zasłynęła z walki ze stereotypami dotyczącymi Chińczyków oraz aktywnie wspierała chiński ruch oporu podczas II wojny światowej.

21 Carmen chinska, „Bluszcz”, nr 44, 31.10.1931, s. 15.

22 R. Czekańska-Heymanowa, U tybetańskiej podróżniczki, „Bluszcz”, nr 4, 23.01.1937, s. 14.

23 A. Krassowska, Jade w Rawskie z. mrs. Fu Liang Changi, „Bluszcz”, nr 23, 5.06.1937, s. 12.

24 E. Kuryło, Teatr chinski, ,Teatr - Wydawnictwo Teatru Polskiego”, czerwiec-sierpień 1931, nr 10, s. 192-194.

25 A.M., $W$ herbacianym domku..., s. 12.

26 E. Theobald, Chińcsylk i Chinka, „Naokoło Świata”, listopad 1935, nr 139, s. 27-32.

27 „Źródło Bogów - legenda chińska”, Aleksander Monoz, „Naokoło Świata”, sierpień 1939, nr 184, s. $73-76$. 
wśród dzieci. Natomiast kiedy kobieta wychodziła za mąż, stawała się członkiem rodziny męża, także po śmierci współmałżonka. Opuszczając własną rodzinę, nie mogła już czcić swoich przodków i tym samym zapewnić przychylności swoim bliskim, a zmarłym spokojnego życia po śmierci. Dlatego w Chinach tak ważne było to, by mieć męskiego potomka i bardziej wyczekiwano syna niż córki ${ }^{28}$.

Aż do początku XX w. małżeństwo w Chinach miało charakter jedynie prywatny, a nie prawny. Podobnie jak w europejskich rodach, stanowiło ono umowę pomiędzy obiema rodzinami, dlatego nierzadko zaręczano ze sobą nawet kilkuletnie dzieci. Z powodu wielożeństwa rozwody były rzadkim zjawiskiem, a mąż nie miał prawa oddalić żony, jeśli jej rodzice nie żyli. Żony miały różny status, chociaż ich dzieci były na tej samej pozycji ${ }^{29}$.

Zgodnie z podstawowymi zasadami konfucjanizmu społeczeństwo jest silnie zhierarchizowane i zrytualizowane, a każdy ma obowiązek odgrywać swoją rolę, z którą łączą się określone zadania i przywileje. Wśród trzech zależności w rodzinie wyróżnia się: zależność syna od ojca, żony od męża oraz młodszego brata od starszego. Zgodnie z tym systemem filozoficzno-religijnym kobieta musiała być „posłuszna w trójnasób”: najpierw wobec ojca, następnie wobec męża i w końcu wobec najstarszego syna. To podporządkowanie się kobiety w rodzinie miało zagwarantować jej ochronę i opiekę w patriarchalnym społeczeństwie, w rzeczywistości jednak często prowadziło do nadużyć. Kobieta cieszyła się swoja godnością i wysoka pozycją dopiero po urodzeniu syna ${ }^{30}$. Co ciekawe, w mitologii chińskiej duże znaczenie miały nie tylko bóstwa męskie, lecz także żeńskie, stanowiące być może ślad dawnego matriarchatu. Kobiety odgrywały też istotną rolę w odłamach taoizmu. W buddyzmie jednak uznawano wcielenie żeńskie za niższe od męskiego ${ }^{31}$.

Chinki ukazywano w polskiej prasie również jako femme fatale. W nowelce Han-su, opublikowanej na łamach „Asa” w 1938 r., tytułowa bohaterka potrafiła zaczarowywać mężczyzn. Ofiarą kobiety padł poważany stary doktor, ponieważ zakochał się w jej portrecie, który ożył. Nieszczęśnik szybko stracił zmysły i popełnił samobójstwo, skacząc w otchłań morza ${ }^{32}$.

W artykułach publikowanych na łamach polskiej prasy codziennej nierzadko pojawiał się motyw Chinek jako wytwornych kurtyzan, które zajmowały znacznie wyższa pozycję w społeczeństwie niż inne kobiety, a sam zawód był szanowany. Według Emila Theobalda, dziennikarza „Z Bliska i z Daleka”, działo się tak, gdyż kobieta trudniąca się tym zajęciem była osobą wolną, szanowaną, wykształconą i niemającą wyrzutów sumienia z powodu wykonywanej pracy, a ponadto zyskiwała

28 E. Kajdański, Chiny leksykon - bistoria, gospodarka, kultura, Warszawa 2005, s. 123-124.

29 M.J. Künstler, Drieje kultury chinskiej, Warszawa 2008, s. 293, 299, 304.

30 Z. Wesołowski, Konfucjańskie podstawy porzadku społecznego i zjanisko „twaray”" [w:] Zrozumieć Chincsylkón - kulturowe kody spoteczności chinskich, red. E. Zajdler, Warszawa 2011, s. 175.

31 M.J. Künstler, Drieje kultury..., s. 268.

32 A. Teodorowicz, Hansu - nowela..., s. 23-25. 
większe szanse na znalezienie zamożnego męża niż przeciętna Chinka ${ }^{33}$. Podobnie w czasopiśmie „Na Szerokim Świecie” czytamy, że we współczesnych chińskich powieściach kurtyzany, które pomimo wykonywanego zawodu były szanowane, miały wyższa pozycję niż żony. Cechowało je bowiem nie tylko piękno, lecz także świetnie wykształcenie: znajomość historii, filozofii, umiejętność pisania wierszy, gry na instrumentach oraz tańca. Dzięki kurtyzanom Chińczycy pozbywali się brutalności i zdobywali ogładę $e^{34}$. Natomiast jeden z korespondentów „Asa” wspominał o zawodowych śpiewaczkach mieszkających i pracujących w dzielnicy, gdzie znajdowały się wytworne restauracje. Oprócz muzykalnego talentu wyróżniały je egzotyczne dla cudzoziemców imiona: „Usta wiosny”, „Kielich narcyza” i „Zielona mimoza". Jak sam twierdził, były one także otwarte na niezobowiązujące relacje, o czym osobiście się przekona ${ }^{35}$. Chociaż według wspominanego autora imiona artystek dodawały im tajemniczości i uroku, to trzeba zauważyć, że tak oryginalne imiona nie były przejawem ekstrawagancji. W Państwie Środka bowiem każde imię ma konkretne znaczenie i, w odróżnieniu od imion europejskich, może być ono całkowicie dowolnie skomponowane, a właśnie żeńskie imiona najczęściej nawiązują do nazw kwiatów ${ }^{36}$. Natomiast według Stanisławy Osińskiej, korespondentki „Bluszczu”, lepszą pozycję od prawowitych żon miały nałożnice, gdyż nie podlegały kurateli teściowej ${ }^{37}$.

W polskiej prasie alarmowano, że sytuacja Chinek była bardzo trudna i wiązała się z ich niska pozycją w społeczeństwie. Wspomniany już Emil Theobald przyrównywał pozycję żony w społeczeństwie chińskim do losu służącej i niewolnicy, gdyż, jak uzasadniał, była ona uzależniona od męża, a w Państwie Środka, szczególnie na wsi, wciąż praktykowano poligamię ${ }^{38}$. Natomiast Janina Mąkolska, dziennikarka „Bluszczu”, powołując się na słowa Jadwigi Stermeckiej, która od 6 lat pracowała w Chinach jako lekarka, twierdziła, że Chinki były zniewolone zarówno duchowo, jak i fizycznie ${ }^{39}$. W innym miejscu dodawała, że już narodziny córki wywoływały wstyd i niezadowolenie, a dziecko często zabijano albo sprzedawano fabrykom „przerabiającym” zdrowe dzieci na potworki, które występowały później na arenach cyrkowych. Ocalałe zaś dzieci nie mogły liczyć ani na opiekę, ani na edukację. Jedynie te z bogatszych rodzin uczono haftu, malarstwa i śpiewu. Stanisława Osińska dodawała, że Chinki były niewolnicami, najpierw podległymi ojcom, a później mężom ${ }^{40}$. Magdalena Lipkowska, korespondentka „Tęczy”, powołując się

33 E. Theobald, Chincsyle i Chinka ..., s. 27-32.

34 Za murem 50000 liter, „Na Szerokim Świecie”, nr 22, 31.05.1936, s. 9.

35 W Pekinie jadtem obiad, „As”, nr 10, 5.05.1935, s. 30.

36 M.J. Künstler, Drieje kultury..., s. 263.

37 S. Osińska, Za chinskim murem, „Bluszcz”, nr 36, 4.09.1937, s. 16-17.

38 E. Theobald, Chińcayle i Chinka..., s. 27-32.

39 J. Mąkolska, Do Chin, „Bluszcz”, nr 14, 6.04.1935, s. 418-419.

40 S. Osińska, Za chińskim murem..., s. 16-17. 
na swój pobyt w China Town w San Francisco, wskazywała, że w przeciwieństwie do mężczyzn kobiety chińskie przesiadywały tylko w domu i nie mogły nigdzie wychodzić - ani do klubu, ani do teatru czy kawiarni ${ }^{41}$. We wspominanej nowelce, Han-Su pojawił się wątek wydawania nieletnich dziewcząt za bogatych mandarynów ${ }^{42}$. Piszący dla „Wschodu” Jan Osiński podkreślał, że pozycja społeczna kobiet w Chinach była bardzo niska, chyba że urodziły syna. Dlatego jedynie teściowa miała stosunkowo wysoką pozycją w rodzinie i cieszyła się nawet większą władzą niż jej odpowiedniczka w Europie ${ }^{43}$.

W prasie wielokrotnie wspominano o krępowaniu stóp Chinkom, które słusznie wskazywano jako jeden z czynników ich niskiej pozycji w społeczeństwie. Najczęściej jednak autorzy artykułów mieli powierzchowną wiedzę na ten temat. Według Stanisławy Osińskiej kobietom bandażowano stopy, aby miały „liliowe” nóżki", i dotyczyło to nie tylko arystokratek, lecz także wieśniaczek wykonujacych ciężkie prace fizyczne ${ }^{44}$. Natomiast główna bohaterka wspomnianej nowelki Han-Su, mimo że miała skrępowane stopy, to stała na malutkich „dziecinnych” nóżkach, na które „założyła pantofle na wysokim obcasie”45. Także Magdalena Lipkowska zapewniała, że w China Town widziała Chinki „z małymi nóżkami”46. Dziennikarze „Z Bliska i z Daleka” wspominali, że rząd chiński bezskutecznie próbował wyplenić zwyczaj krępowania kobietom stóp. Jak błędnie wyjaśniali korespondenci, Chinki zgodnie z tradycją nie miały zdeformowanych stóp, a jedynie nosiły małe, ciasne, niehigieniczne buciki ${ }^{47}$. Również w „Bluszczu” pisano o tej reformie. Czytamy w nim, że władze, chcąc uregulować modę kobiecą, zakazały przede wszystkim wyrobu i sprzedaży europejskich sukienek oraz obuwia, które krępowało i zmniejszało stopy, a ponadto ze względu na „zachodnią niemoralność" zabroniono używania pudru i szminki ${ }^{48}$. Natomiast jeden ze współpracowników „Asa” przyrównał krępowanie stóp do kreowania miniaturowych drzewek, tj. bonsai. Aby uzyskać ten niezwykły efekt, drzewka miały tak samo cierpieć jak mieszkanki Państwa Środka: „Prawie wszystkie karłowate drzewa tkwią w płytkich naczyniach porcelanowych, których glazura nie przepuszcza powietrza. Mała tę ilość ziemi, więc nie pożywną, podlewa się skąpo, a pień od młodości ściska się, krępuje, nacina, wykręca; słowem dręczy się go, jak Chinka swe biedne nóżki.

\footnotetext{
41 M. Lipkowska, China Town, „Tęcza”, sierpień 1937, nr 8, s. 53.

42 A. Teodorowicz, Hansu - nowela..., s. 23-25.

43 J. Jaworski, Udziat tajnych zuviqzkón w rewoluciji chinskiej, „Wschód”, czerwiec-grudzień 1933, nr 11-12, s. 45-46.

${ }^{4}$ S. Osińska, Za cbińskim murem..., s. 16-17.

45 A. Teodorowicz, Hansu - nowela..., s. 23-25.

46 M. Lipkowska, China Town..., s. 53.

47 Usuwanie śladów podboju Chin præ̨ez Mandìurów, „Z Bliska i z Daleka”, styczeń 1935, nr 19, s. 26.

48 Rzqad chinski reguluje mode kobieca, „Bluszcz”, nr 25/26, 22-29.06.1935, s. 797.
} 
Wynikiem takich tortur jest zahamowanie wzrostu drzewka, w związku z pokrzywieniem pnia" ${ }^{49}$.

Autorzy czasopism dobrze kojarzyli zwyczaj krępowania stóp z Państwem Środka i słusznie wskazywali, że był on jedną z form ograniczenia aktywności kobiet, świadczył również o ich wyjątkowo złej sytuacji w społeczeństwie. Mimo to wiele informacji na ten temat było nieprawdziwych, wskazując na jedynie powierzchowną znajomość problematyki. Krępowanie stóp było szczególnie okrutnym zwyczajem, polegał bowiem na wielotygodniowym deformowaniu i łamaniu stóp, które za pomocą bandaża trwale i stopniowo coraz ciaśniej zawijano do wewnątrz. Nieprawdziwe były doniesienia o tym, że kobiety, mając skrępowane stopy, ubierały buty na wysokich obcasach, oraz że używano obuwia zmniejszającego bądź krępującego stopy. Ostatecznie zwyczaj ten, istniejący od X w., został prawnie zakazany dopiero w 1911 r., dzięki wysiłkom reformatora Kang Youweia oraz pierwszego prezydenta Republiki Chińskiej Sun Yat Sena. Wcześniej bezskuteczne próby zakazania tej praktyki podejmowali w XVII w. cesarz Kangxi, a później Tajpingowie i Mandżurowe, którzy, co warto zaznaczyć, nigdy jej nie stosowali ${ }^{50}$.

Przywołany wyżej artykuł informujący o reformie stroju kobiecego nawiązywał do Ruchu Nowego Życia, propagowanego przez Czang Kaj-sheka i jego żonę Meiling Song. Organizacja ta głosiła konfucjańskie zasady przyzwoitości, sprawiedliwości, uczciwości i szacunku do samego siebie i dążła do odnowy moralnej narodu. Przywódca Kuomitangu uważał bowiem, że kryzys w państwie wynikał z niedostatecznego rozwoju duchowości Chińczyków. W 1935 r. w Nankinie opublikowano listę zawierającą 86 poleceń, które miały stanowić zachętę dla mieszkańców do praktykowania prostoty, oszczędności i dobrego zachowania. W jednym z punktów zakazywano kobietom noszenia ,lubieżnych lub ekstrawaganckich strojów", a dodatkowo władze prowincji Jiangxi sformułowały szczegółowe zasady dotyczące kobiecych sukni i fryzur. Niektóre z zasad propagowanych przez Ruch Nowego Życia, takie jak zakaz handlu i palenia opium czy zakaz nadużywania alkoholu, przyczyniły się do poprawy bytu społeczeństwa. Jednak nowe regulacje najczęściej zamiast rozwiązywać istotne problemy odnosiły się do najdrobniejszych aspektów życia codziennego, jak chociażby nakazu jedzenia w ciszy i wczesnego chodzenia spać ${ }^{51}$.

Sytuację kobiet na Dalekim Wschodzie zmieniały ruchy feministyczne. W Państwie Środka najszybciej emancypowały się kobiety w miastach, podczas gdy sytuacja kobiet na wsi, pomimo starań aktywistek, podobnie jak w Europie pozostawała niezmienna.

\footnotetext{
49 Z.K., Karly i olbryymy japońskie, „As”, nr 4, 24.01.1937, s. 26.

50 R.Y. Eng, Foot-binding [w:] Encyclopedia of China, eds. L. Cheng, K. Brown, vol. 2, Berkshire 2009, s. 846-847; E. Kajdański, Chiny leksykon..., s. 107, 120; W. Sidichmienow, Chiny. Karty præęszłości, tłum. A. Bogdański, Warszawa 1978.

51 J. Fenby, Czang Kaj-szek i jego Chiny, tłum. J. Włodarczyk, Wrocław 2003, s. 261-266; T. Łozińska, Myśl polityczna Czang Kaj-szekea, Kraków 2017, s. 146-153.
} 
Do najważniejszych przedstawicielek tego ruchu należały: doktor prawa Zheng Yuxiu (Soume Tcheng), Louise Huje Chang oraz trzy siostry Song: Qingling - wdowa po prezydencie Sun Yat Senie, Ailing (Regina) - żona ministra finansów Xiangxi Konga (Hsiang-hsi. Kunga), Meiling Song - żona Czang Kaj-sheka ${ }^{52}$.

Dziennikarze, informując o emancypacji kobiet na Dalekim Wschodzie, nierzadko akcentowali, że wyzwolone Chinki podejmowały pracę w zawodach zarezerwowanych wcześniej tylko dla mężczyzn. Najliczniejsze wiadomości na ten temat przekazywały pisma kobiecie, zwłaszcza „Bluszcz” i „Ziemianka Polska”.

Według korespondentów doskonałym przykładem emancypacji kobiet w Azji miała być działalność żony Czang Kaj-sheka - Meiling Song. Pisząc na ten temat, koncentrowano się jednak głównie na elitach. Korespondent „Bluszczu” zaznaczył, że należała ona do najbardziej zaufanych i wpływowych członków sztabu generała i była jego adiutantka, a także świetną pilotka, brawurową szoferką, oficjalną tłumaczką z języka angielskiego, francuskiego i niemieckiego, dyplomatką i kierowniczką patriotycznej organizacji Nowe Życie ${ }^{53}$. Co więcej, jako jedyna kobieta brała udział w posiedzeniach najwyższej rady obrony państwa ${ }^{54}$. Jej niezwykła pozycję w chińskiej polityce i sławę odważnej pilotki podkreślał również „Przegląd Katolicki”. Dodał przy tym, że jej dwie siostry też miały silną pozycję w kraju: Qingling jako żona prezydenta Sun Yat Sena oraz Ailing jako żona ministra H.H. Kunga (Kong Xiangxi). W przeciwieństwie do „Bluszczu” uznał wysoka pozycję Meiling Song i jej sióstr w Chinach nie za godna podziwu, lecz dziwną, gdyż jak podsumował: „ciekawy to kraj, w którym kobiety odgrywają taką rolę"55. Roman Fengler na łamach „Tęczy” dodawał, że w modernizacji Chin duże znaczenie miała działalność prowadzona przez „światłą małżonkę” Czang Kaj-sheka i szwagierkę Sun Yat Sena - Meiling Song ${ }^{56}$.

Dziennikarze jednak nie wspominali o negatywnych cechach członków rodziny Meiling Song. Ailing Song miała być znana ze swej miłości do pieniędzy, które zdobywała, wykorzystując ministerialne stanowisko męża. Natomiast Meiling Song, choć popierała Ruch Nowe Życie, nierzadko sama się nie dostosowywała do jego zasad, np. paliła papierosy. Ponadto niektóre zasady tego ruchu ograniczały swobodę kobiet, np. zasada dotycząca skromnego ubioru. Znacznie większą hipokryzję przejawiał jednak jej mąż, ponieważ oficjalnie zwalczał palenie opium, a mimo to utrzymywał kontakt z szanghajskim gangsterem Wielkouchym Du oraz gubernatorami, którzy wzbogacali się na handlu tym narkotykiem. W artykułach pomijano lub tylko pobieżnie wzmiankowano o bracie Ailing, Meiling i Qingling - Ziwei Songu,

52 S. Osińska, Za chińskim murem..., s. 16-17.

53 Meiling Czang-Kai-Szek, „Bluszcz”, nr 32, 7.08.1937, s. 19.

54 J. Hałaciński, Wojna chińsko-japońska (cææeśc 2), „Żołnierz Polski”, nr 30, 21.11.1937, s. 713.

55 Wielka rozgrywka w Azji, ,Przegląd Katolicki”, nr 50, 8.08.1937, s. 504.

56 R. Fengler, „Nowe sycie”..., s. 40. 
który był ministrem finansów i wraz ze swoim szwagrem (Kong Xiangxi) zajmował się reformą gospodarki ${ }^{57}$.

Pisząca dla „Ziemianki Polskiej” Eleonora Lubomirska również stwierdziła, że pomimo wielu przeciwności Chinki zaczęły odgrywać coraz większą rolę w polityce. Przykładem dla Polek miała być historia pani Huang, piastującej urząd konsula w Londynie. Aby skończyć studia prawnicze i wspomóc liczne rodzeństwo, pracowała wcześniej jako sprzedawczyni, kelnerka, a także urzędniczka w towarzystwie transportowym ${ }^{58}$. Inną obywatelką Państwa Środka, która osiągnęła wysokie stanowisko, była Won Lee Morton, kierowniczka Ministerstwa Opieki nad Dzieckiem ${ }^{59}$. Natomiast w prowincji Henan, gdzie przyznano kobietom pełną równość praw, wybrano pierwszą posłankę do parlamentu w Pekinie ${ }^{60}$. Nie dziwi zainteresowanie tą tematyką w polskich czasopismach, gdyż Polki chcące działać w polityce w ówczesnej epoce musiały przezwyciężyć wiele trudności. W Polsce kobiety uzyskały prawa wyborcze już w 1918 r., a w 1919 r. do sejmu dostało się 8 kobiet i to pomimo dyskryminujących je zasad przy wpisywaniu na listy wyborcze. Z zasady otrzymywały one ostatnie, najgorsze miejsca na listach wyborczych. Mimo to w dwudziestoleciu międzywojennym w ławach sejmowych zasiadły 32 posłanki oraz 18 senatorek, przy czym żadna $z$ nich nie pełniła funkcji w rządzie ${ }^{61}$.

Eleonora Lubomirska podkreślała, że Chinki dobrze radziły sobie nie tylko w polityce. Kolejnymi bohaterkami były Wang - założycielka znanego dziennika w Pekinie $^{62}$ oraz Mylen-Sok-Wo - dyrektorka wielkiego szanghajskiego banku kobiecego. W odniesieniu do tej ostatniej zaznaczono, że po dekadzie kapitał prowadzonego przez nią banku z 200 tys. USD wzrósł do 500 tys. USD, a rezerwy do $5 \mathrm{mln} \mathrm{USD}^{63}$. Równie zasłużoną dla chińskiego przemysłu stała się dr Feng-Yuan-O, która odkryła, że z rośliny sorgo można fabrykować jedwab nieustępujący w niczym sztucznemu, a jego wyrób był o wiele tańszy ${ }^{64}$. Współpracująca z „Asem” Matylda Sapieżanka również pisała o pomyślnie rozwijającym się ruchu emancypacyjnym w Chinach. Według niej świadczyła o tym kariera Sang Mi Han - żony ministra Chang Hsin Haia. Wyjaśniała, że była ona nie tylko młoda, urodziwą i interesującą kobietą, ale przede wszystkim profesorem angielskiej i chińskiej literatury oraz tłumaczką ${ }^{65}$.

57 W. Chai, S. Mei-ling [w:] Encyclopedia of China..., s. 2049-2050; J. Fenby, Czang Kaj-szek..., s. 10-11; D.D. Buck, S. Ziwei [w:] Encyclopedia of China..., s. 2051-2052.

58 E. Lubomirska, Kronika Kobieca - Chiny, „Ziemianka Polska”, marzec 1938, nr 3, s. 21.

59 Ibidem.

60 E. Lubomirska, Kronika Kobieca - Chiny, „Ziemianka Polska”, grudzień 1934, nr 12, s. 28.

61 A. Zaprutko-Janicka, K. Janicki, R. Kuziak, D. Kaliński, Præ̌edwojenna Polska w lič̨ach, Kraków 2020, s. 228-233.

62 E. Lubomirska, Kronika Kobieca - Chiny, „Ziemianka Polska”, marzec 1938, nr 3, s. 21.

63 E. Lubomirska, Kronika Kobieca - Chiny, ,Ziemianka Polska”, grudzień 1934, nr 12, s. 28.

64 E. Lubomirska, Kronika Kobieca - Chiny, „Ziemianka Polska”, lipiec 1936, nr 7, s. 25.

65 M. Sapieżanka, Herbata u ministrowej Chang Hsin Hai, „As”, nr 7, 16.02.1936, s. 26. 
Według dziennikarek „Bluszczu” sytuację kobiet z Państwa Środka mogła zmienić dopiero ówczesna wojna, ponieważ tak samo jak ich ojcowie, mężowie i bracia walczyły one z wrogiem, stając się tym samym inspiracją dla swoich rodaczek mieszkających na wsi ${ }^{66}$. Zofia Mycielska, współpracująca z "Ziemianką Polską”, dodała, że na czele ruchu niepodległościowego w Mandżurii stanęła Yao-Lej ${ }^{67}$, a w Szanghaju medalem Legii Honorowej odznaczono siostrę Marię z zakonu Sióstr Szarytek Miłosierdzia ${ }^{68}$. Niewymieniona z imienia dziennikarka pisząca dla „Bluszczu” przytoczyła także historię Sun Czi Me, którą przyrównała do Joanny d’Arc, bowiem Sun pragnęła wstąpić do wojska i walczyć z okupantem w Mandżurii. Ponieważ była kobieta, odmawiano przyjęcia jej do służby w siłach Chin Północnych, dlatego zgłosiła się do dowódcy armii południowochińskiej gen. Ma Zhanshana ${ }^{69}$. Chinki służyły przede wszystkim w lotnictwie, stanowiąc $10 \%$ wyszkolonych pilotów ${ }^{70}$. Pierwszą obywatelką Państwa Środka, która zasiadła za sterami samolotu i służyła w wojskowej flocie, była Wan Kwei Ten ${ }^{71}$, a pierwsza pilotką Lea Hing ${ }^{72}$.

Zarówno „Bluszcz”, jak i „Ziemianka Polska” donosiły, że w większych chińskich miastach pojawiły się policjantki - zajmowały się one opieką nad kobietami i dziećmi. Pierwszą metropolia, w której Chinki mogły znaleźć zatrudnienie w tym zawodzie, był Pekin, a do służby zgłosiło się tysiąc kobiet, przeważnie inteligentek i studentek. Tymczasem w Szanghaju w tym zawodzie pracowało 25 Chinek $^{73}$.

Inną ścieżką emancypacji dla kobiet w Państwie Środka były sztuka i sport. Wśród Chinek, który zrobiły światową karierę w tych dziedzinach, znalazły się literatka Voung - Kka Zam oraz aktorka Helen Wang. Pierwsza z nich za swoją powieść Kobiety Wschodu została uhonorowana złotym medalem. Autor notatki zamieszczonej w „Bluszczu” donosił, że pisarka była feministką i pierwszą kobietą wyróżnioną tak wysokim odznaczeniem ${ }^{74}$. Natomiast Helen Wang zasłynęła nie tylko talentem aktorskim, lecz także otworzyła cieszący się dużą popularnością salon piękności w Szanghaju ${ }^{75}$. Jeden z dziennikarzy „Asa” wspominał ponadto o międzynarodowej karierze Anny May Wong - chińskiej gwiazdy filmowej. W przeciwieństwie do „Bluszczu” wskazywał, że odniosła ona sukces nie z powodu swoich umiejętności,

66 S. Osińska, Za chińskim murem..., s. 16-17.

67 Z. Mycielska, Wiadomości z. ragranicy - ze świata - Chiny, „Ziemianka Polska”, styczeń 1934, nr 1, s. 28.

${ }^{68}$ Zakonnica odznaczona Legja Honorowa, „Bluszcz”, nr 5, 30.01.1932, s. 15.

69 Egrotyczna kandydatka na bohaterke, „Bluszcz”, nr 3, 16.01.1932, s. 15.

70 E. Lubomirska, Kronika Kobieca - Japonia, „Ziemianka Polska”, marzec 1935, nr 3, s. 30.

71 Chinki tę̇ lataja, „Bluszcz”, nr 2, 9.01.1932, s. 14.

72 Pierwsza i dotychczas jedyna lotniczka chinskea, „Bluszcz”, nr 21, 21.05.1932, s. 15.

73 Kobieca policja w Chinach, „Bluszcz”, nr 4, 28.01.1933, s. 18; E. Lubomirska, Kronika Kobieca-Chiny, „Ziemianka Polska”, maj 1937, nr 5, s. 19; eadem, Kronika kobieca - Chiny, „Ziemianka Polska", listopad 1933, nr 11, s. 27.

74 Odznaczenie chińskiej literatki, „Bluszcz”, nr 22, 2.06.1934, s. 674.

75 Chinki chca być moderne, „Bluszcz”, nr 28, 11.07.1931, s. 5. 
lecz egzotycznej urody, dzięki której była również jedną z najciekawszych modelek dla malarzy. Dodawał, że wśród jej portrecistów znalazł się amerykański artysta Thomas Handforth, a szkice jego autorstwa z wizerunkiem Anny May Wong na aukcji w Nowym Jorku osiagnęły rekordowe ceny ${ }^{76}$. W „Życiu Sztuki” przekonywano, że Chinki znacznie częściej niż Chińczycy należały do amatorskich klubów teatralnych $i$ wystawiały sztuki o charakterze patriotyczno-społecznym, poruszające takie problemy, jak nielegalny przemyt towarów przez Japończyków i Koreańczyków ${ }^{77}$. „Bluszcz” zaś donosił, że wśród chińskich zawodniczek wyróżniała się trzynastoletnia Gen Hoafiny, która zdobyła mistrzostwo na dziecięcych zawodach tenisowych w Middleres ${ }^{78}$.

W prasie polskiej wspominano także o działalności charytatywnej kobiet w chrześcijańskich stowarzyszeniach. Ignacy Krauze w swoim liście, który opublikowała „Tęcza”, wskazywał, że w Czengtifu prężnie działało zgromadzenie sióstr Józefinek, do którego należały mieszkanki Państwa Smoka ${ }^{79}$.

Najwięcej miejsca informacjom o mieszkankach Państwa Środka poświęcały czasopisma kobiece, takie jak „Bluszcz”, oraz czasopisma masowe „As” i „Na Szerokim Świecie”, których odbiorcami były zazwyczaj obywatelki II Rzeczypospolitej ${ }^{80}$.

W polskiej prasie Chinki ukazywano albo jako tajemnicze kobiety o egzotycznej urodzie i tajemniczej duszy, ofiary patriarchalnego systemu, albo jako emancypantki walczące o swoje prawa w życiu politycznym, zawodowym i społecznym. Przy czym czasopisma masowe skupiały się na ukazywaniu ich zewnętrznego wyglądu, rzadziej zaś na cechach charakteru, dokonując zazwyczaj wyraźniej stereotypizacji. Niestety mieszkankom Państwa Środka przypisywano zwykle jedynie przywary: brak wykształcenia i bycie femme fatale. Szczególnie krzywdzące i niesprawiedliwe przekonanie na temat charakteru Chinek mówiło o tym, że były one nieobyte i wyrachowane, ponieważ oczekiwały od mężów jedynie pieniędzy. Stwierdzenie to zdradza ignorancję dziennikarza „Naokoło Świata”, jego nieznajomość sytuacji społecznej kobiet w ówczesnych Chinach. Tylko bowiem w nielicznych przypadkach Chinki miały szansę na podjęcie pracy i zarabianie pieniędzy, najczęściej zaś wykonywały nieodpłatną pracę w domu i gospodarstwie, zdane na łaskę męża.

Zarówno czasopisma masowe, jak i kobiecie skupiały się na ukazaniu sytuacji społecznej Chinek, sygnalizując przy tym, że była ona mniej korzystna niż sytuacja Polek w II Rzeczypospolitej. W ten sposób poniekąd usprawiedliwiano rząd polski, że niewiele robi w kwestii przezwyciężania dyskryminacji kobiet. Jako przykład złego traktowania Chinek podawano zwyczaj krępowania stóp. Nierzadko jednak zaznaczano w tekstach prasowych, że pozycja obywatelek Państwa Środka szybko

76 Anna May Wong pozuje..., s. 27.

77 Y. Hovo-Joei, Życie sætuki za granica - Chiny, „Życie Sztuki” 1939, s. 256-258.

78 Traynastoletnia Chinka, angielska mistraynia Tenisa, „Bluszcz”, nr 38, 22.09.1934, s. 1191.

79 I. Krauze, W'śód skośnookich neofitów - list ₹ głębi Chin, „Tęcza”, nr 16, 18.04.1931, s. 13.

80 A. Paczkowski, Prasa polska w latach 1918-1939, Warszawa 1980, s. 249-251. 
się polepszała, choć nadal do ich emancypacji wiodła długa droga, ponieważ zmiany najczęściej były tylko powierzchowne i wiązały się z modernizacją i westernizacja. Jako główną przeszkodę w realizacji równouprawnienia kobiet wskazywano na wciąż silne wpływy konfucjanizmu w chińskim społeczeństwie.

Dziennikarki współpracujące z czasopismami kobiecymi najczęściej skupiały się na ukazaniu zmagań i sukcesów mieszkanek Państwa Środka w walce o równouprawnienie. Ich działania miały być również inspiracją dla Polek, które podobnie jak mieszkanki Azji musiały walczyć z niesprawiedliwym dla nich prawem pracy. Dlatego też zarówno na łamach „Bluszczu”, jak i „Ziemianki Polskiej” korespondentki kładły większy nacisk na emancypację zawodową obywatelek Państwa Środka niż na ich walkę z innymi przejawami dyskryminacji płciowej.

Z kolei współpracownicy katolickiej „,Tęczy” akcentowali znaczenie chrześcijańskich organizacji oraz chrześcijańskiej moralności w poprawie losu i emancypowaniu się obywatelek Państwa Środka.

Dziennikarze starali się obalać powszechne w omawianym okresie stereotypy na temat mieszkańców Chin, mimo to jednocześnie powstawało wiele nowych przekłamań, które często wynikały z niewiedzy autorów artykułów bądź też z postrzegania wydarzeń przez pryzmat własnych doświadczeń i zainteresowań. Przykładem może być chociażby koncentrowanie się jedynie na pozytywnych aspektach działalności Meiling Song i jej roli w emancypacji chińskich kobiet.

\section{Literatura}

Bachórz J., „Prawda” Aleksandra Świętochowskiego o chińskim Powstaniu Bokserów [w:] Chiny w oczach Polaków, red. J. Włodarski, K. Zeidler, M. Burdelski, Gdańsk 2010.

Buck D.D., Soong Ziwei [w:] Encyclopedia of China, eds. L. Cheng, K. Brown, vol. 4, Berkshire 2009. Eng R.Y., Foot-binding [w:] Encyclopedia of China, eds. L. Cheng, K. Brown, vol. 4, Berkshire 2009. Fenby J., Crang Kaj-szek i jego Chiny, tłum. J. Włodarczyk, Wrocław 2003.

Kajdański E., Chiny lekesykeon - historia, gospodarka, kultura, Warszawa 2005.

Künstler M.J., Drieje kultury cbińskiej, Warszawa 2008.

Lozińska T., Myśl polityczna Cz̨ang Kaj-sz̨eka, Kraków 2017.

Paczkowski A., Prasa polska w latach 1918-1939, Warszawa 1980.

Sidichmienow W., Chiny. Karty pržeszłości, tłum. A. Bogdański, Warszawa 1978.

Wesołowski Z., Konfucjanskie podstawy porz̨qdku spotecznego i zjawisko „,twarsy” [w:] Zrozumieć Cbińczyków - kulturowe kody społeczności chinskich, red. E. Zajdler, Warszawa 2011.

Winberg Ch., Soong Mei-ling [w:] Encyclopedia of China, eds. L. Cheng, K. Brown, vol. 4, Berkshire 2009.

Zaprutko-Janicka A., Janicki K., Kuziak R., Kaliński D., Pržedwojenna Polska w liç̨bach, Kraków 2020. 


\section{Źródła}

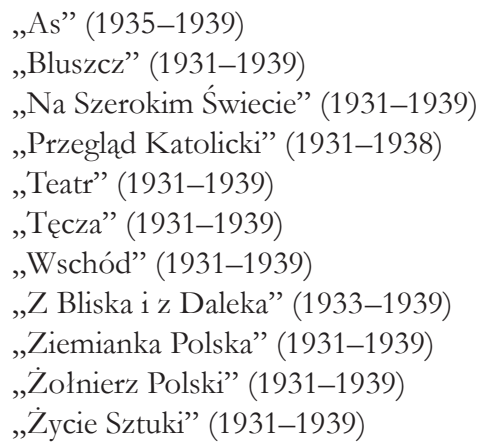

\section{SUMMARY}

\section{THE IMAGE OF CHINESE WOMEN IN SELECTED POLISH INTERWAR PRESS IN THE 1930S}

Among the interests of the pre-war press, both mass and specialized, was China. Most of the space was devoted to the inhabitants of the Middle Kingdom: "Ivy" and mass magazines, associated with the Ilustrowany Kurier Codzienny [lllustrated Daily Courier], whose readers were also usually female citizens of the Second Polish Republic: As [Ace] and $\mathrm{Na}$ Szerokim Świecie [In the Broad World]".

In the Polish press, Chinese women were presented either as mysterious women of exotic beauty, who used to have mysterious souls, victims of the patriarchal system, or emancipated women fighting for their rights in political, professional and social life. Mass magazines often focused primarily on both the external appearance and spirituality of the Chinese. However, while the inhabitants of the Middle Kingdom were described as beautiful and elegant women, their character was usually portrayed in a negative light. It was emphasized that many of them served as not only charming, but well-educated courtesans. Both mass magazines and the women's press were alarmed that the situation of Chinese women was very severe and was due to their low position in society. As a significant example, they gave the habit of foot binding.

The women's press, however, further emphasized that the situation of Chinese women gradually improved thanks to feminist movements. And among the most important representative women's press mentioned Meling Sung. Both Bluszcz. [Ivy] and Ziemianka Polska [Polish Lady Landowner] placed more emphasis on the professional emancipation of citizens of the Middle Kingdom than on their fight against other manifestations of gender discrimination. 